\section{Long-term Short Implants Performance: Systematic Review and Meta-Analysis of the Essential Assessment Parameters}

Thais Marques Simek Vega Gonçalves' ${ }^{1}$ Sergio Bortolini' ${ }^{2}$, Matteo Martinolli2, Bruna Fernandes Moreira Alfenas ${ }^{3}$, Daiane Cristina Peruzzo ${ }^{4}$, Alfredo Natali ${ }^{2}$, Andrea Berzaghi², Renata Cunha Matheus Rodrigues Garcia ${ }^{3}$

\author{
'Department of Dentistry, UFSC \\ - Universidade Federal de Santa \\ Catarina, Florianópolis, SC, Brazil \\ ${ }^{2}$ Department of Dental Materials, \\ University of Modena and \\ Reggio Emilia, Modena, Italy \\ ${ }^{3}$ Department of Prosthodontics and \\ Periodontology, Piracicaba Dental \\ School, UNICAMP - Universidade de \\ Campinas, Piracicaba, SP, Brazil \\ ${ }^{4}$ Department of Oral Pathology, \\ Division of Periodontics, SLMANDIC \\ - Faculdade São Leopoldo \\ Mandic, Campinas, SP, Brazil.
}

Correspondence: Profa. Dra. Renata Cunha Matheus Rodrigues Garcia, Avenida Limeira, 901, 13414-903 Piracicaba, SP, Brasil. Tel: +55-19-2106-5240. e-mail: regarcia@fop.unicamp.br

Key Words: short dental implants, treatment outcomes, failures, complications, clinical success.

\section{Introduction}

In the past, short implants were commonly associated with lower survival rates due to the reduced bone-toimplant contact allied to the fact that short implants are mostly installed in the posterior zone, once the quality of the alveolar bone is relatively poor (1-3). Moreover, the posterior region commonly presents moderate to extensive resorption, which results in very outsized crowns and a high crown-to-implant ratio when short implants are placed (4). In this sense, it is reasonable to suppose that the long-term performance of such implants is reduced; however, recent literature has demonstrated no significant differences in the survival rate reported by short and standard implants $(5,6)$.

The development of modified implant designs and surfaces including different micro-topography and chemistry might probably have contributed for the increased survival rates of short implants $(1,4)$. Nevertheless, standard outcome criteria to assess the clinical performance of the short implants are still missing in literature, becoming difficult to draw conclusions. Considering that these criteria would be used during subsequent appointments after the insertion of short implants, it could configure as an important instrument for the decision-making process on the future clinical interventions. Furthermore, the related decision should be derived from the highest level of evidence such as a systematic review (7). Thus, this article summarizes, through a systematic review of the literature, the essential parameters required to assess the long-term clinical performance of short and extra-short dental implants, allowing standard comparisons in future studies.

\section{Material and Methods Search Strategy and Study Selection}

An electronic search, without language restriction, was conducted to identify studies focused on the clinical performance of short and extra-short dental implants. For that purpose, PubMed/MEDLINE, EMBASE, LILACS, and Cochrane Library databases were searched between the period of January 2000 and March 2014. The search was limited to the following filters from the referred website: "Clinical Trial", "Randomized Clinical Trials", "Prospective Studies", and "Humans". The key words used in this search 
were "short dental implants", "short dental implants" [MeSH term] AND "treatment outcomes", "short dental implants" [MeSH term] AND "failures", "short dental implants" [MeSH term] AND "complication", "short dental implants" [MeSH term] AND "biologic complication", "short dental implants" [MeSH term] AND "alveolar bone loss", "short dental implants" [MeSH term] AND "bone loss", "short dental implants" [MeSH term] AND "success", "short dental implants" [MeSH term] AND "clinical success".

Titles and abstracts of the searched papers were initially screened by two independent reviewers for possible inclusion. A further search was performed through the bibliographies of all relevant articles. Any discrepancies between the reviewers were discussed until a consensus was reached. Cohen's Kappa-coefficient was calculated as a measure of agreement between the two readers, revealing an excellent degree of accordance $(\mathrm{K}=0.83)$.

\section{Inclusion Criteria}

The first author created a search strategy in which all the titles and abstracts of the studies were examined and relevant studies selected. The selection criteria included:

- all types of randomized or prospective clinical trials, conducted in humans, with a clear aim of investigating the long-term performance of short implants exclusively (less than $10 \mathrm{~mm}$ in total length and $8 \mathrm{~mm}$ intrabone length);

- studies with reported implant survival rates as well as criteria for implant failure;

- studies had to have a minimum sample size of 10 healthy patients and a minimum number of 10 short implants installed, with mentioned mean follow-up period of at least 1 year after implant loading with the prosthesis.

In this review, a wide range of inclusion criteria to obtain general findings was included without differentiating implant type, surgical procedure technique, patient characteristics or prostheses type.

\section{Exclusion Criteria}

Animal studies, retrospective studies, case reports, reviews, non-clinical studies, explanation of technique or clinical trials with insufficient information regarding the long-term performance of short implants were not considered to avoid any risk of bias. Studies using short and standard implants to support the same prostheses were also excluded.

\section{Data Extraction}

Based on the inclusion and exclusion criteria, selected potential articles were obtained in full text. The data extracted included the following: study design, number of subjects at baseline, number of implants at baseline, implant length $(\mathrm{mm})$, implant system, location, type of prosthesis, prosthesis' material, loading protocol, type of implant surface, type of implant-abutment connection, follow-up regularity, follow-up years after loading, drop-outs, number of implants in the follow-up, clinical performance assessment, training and calibration, biological parameters evaluated, biological complication, mechanical complication, esthetical complication, references to measure marginal bone loss, marginal bone loss measured, crown-to-implant ratio, implant failure, prosthetic failure, cumulative implant survival, and cumulative prosthesis survival. To fill in missing or inadequately reported data, we attempted to obtain information by contacting the authors by e-mail. Unfortunately, the contacted authors did not respond on either of the attempts for obtaining more details about the study. On the other hand, no missing information was stronger enough to exclude or jeopardize the analysis of the selected studies.

\section{Method of Analysis}

All extracted data of the selected articles were doublechecked and pulled out in the Tables 1 and 2. A sensitivity analysis was conducted to check the robustness of the pooled results with regard to study by removing them one by one. After a preliminary evaluation, it was found substantial heterogeneity among the studies which could jeopardize a quantitative analysis. Thus, only the cumulative implant survival rate percentage (CSR\% - confidence interval 95\%) based on the failure time reported allows meta-analysis. Consequently, a more descriptive data analysis was chosen for the remaining parameters. Metaanalysis was performed considering the fixed and random effects models and statistical heterogeneity was assessed by means of $\mathrm{I} 2$ statistics. All the analyses were performed with Comprehensive Meta-Analysis Software (Version 3, BioStat, Englewood, NJ, USA).

\section{Results}

\section{Study Characteristics}

The search from the electronic databases identified a total of 1174 titles of short implants studies, out of which 804 were excluded after discussion. From the 370 titles selected, only 185 abstracts were electable to search for detailed analysis based on inclusion criteria. Among them, 44 articles were selected to full text analysis. Additional searching on their bibliographies provided 3 more studies, with a total of 47 articles in the full text evaluation. Finally, 34 articles were excluded based on the exclusion criteria. This resulted in a final number of 13 publications for the current review (Fig. 1).

\section{Overall Characteristics of the Included Studies}

The 13 studies that met the inclusion criteria are 


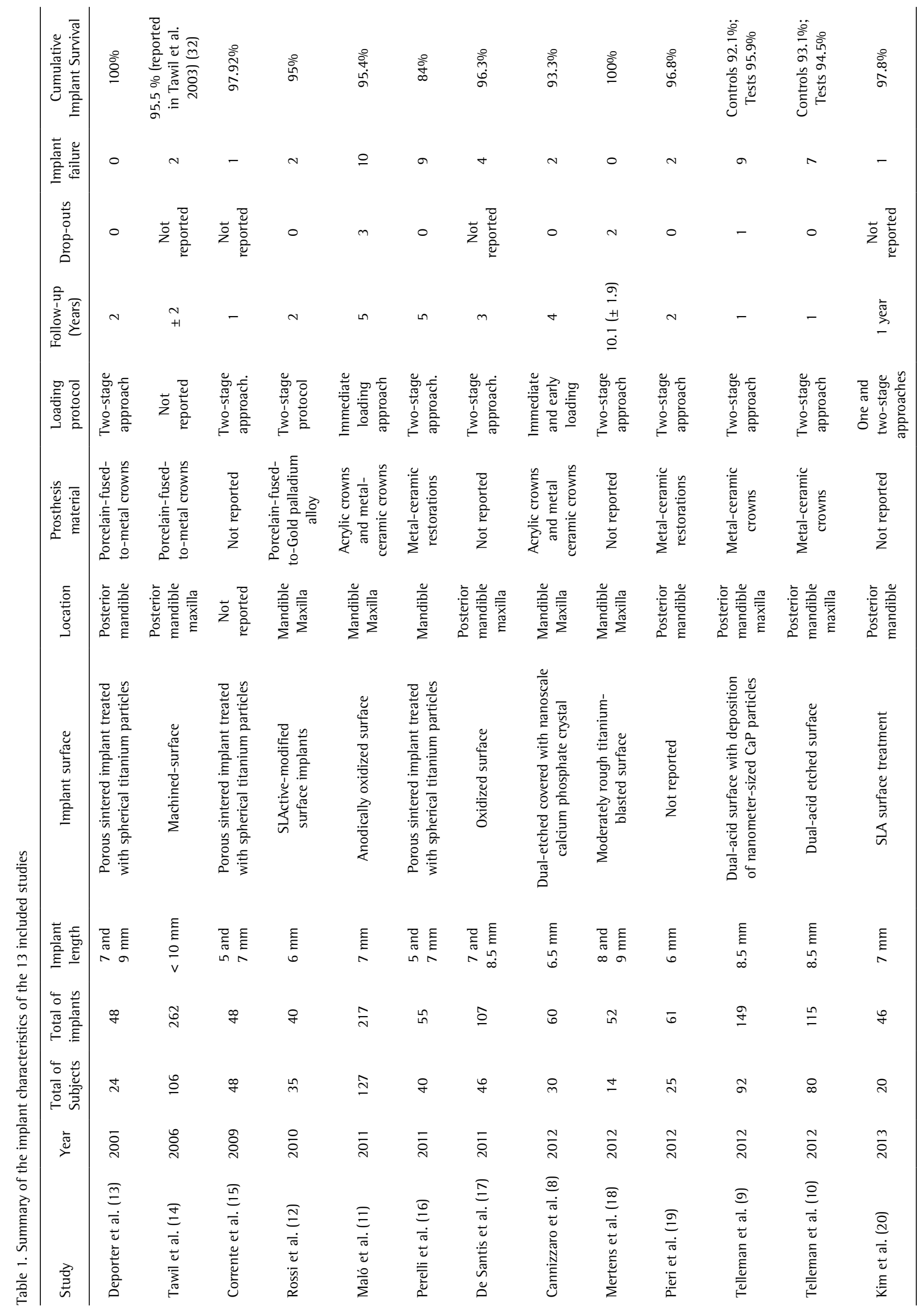

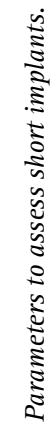


summarized in Table 1. Among these selected articles, three were randomized clinical trials (8-10), two were prospective cohort studies $(11,12)$, and the remaining eight were prospective studies (13-20). The patients were majority treated at university settings ( 5 studies) or in private dental clinics (3 studies), but one study (17) has a multicenter approach, combining results from patients treated in an academic environment and two private offices. Such information was not provided in the remaining four studies.

A total number of 1260 implants were placed in 687 patients with age range 18-80 years (Table 1 ). The followup period varied from 1 to 10 years while the dropout rate ranged from $0 \%$ to $14.3 \%$. Most of studies specified the region where the implants were placed, being the

Table 2. Summary of the main methods of implant analysis applied in the 13 included studies

\begin{tabular}{|c|c|c|c|c|}
\hline Reference & $\begin{array}{l}\text { Implant } \\
\text { length }\end{array}$ & $\mathrm{X}$-ray technique & Calibration & Marginal bone \\
\hline $\begin{array}{l}\text { Deporter } \\
\text { et al. (13) }\end{array}$ & $\begin{array}{l}7 \text { and } \\
9 \mathrm{~mm}\end{array}$ & $\begin{array}{l}\text { Customized acrylic resin } \\
\text { templates and standard long } \\
\text { cone paralleling technique }\end{array}$ & Not reported & $\begin{array}{l}\text { Position of the alveolar bone at the } \\
\text { machined/porous surface junction } \\
\text { of the implant root component }\end{array}$ \\
\hline $\begin{array}{l}\text { Tawil et } \\
\text { al. (14) }\end{array}$ & $\begin{array}{l}<10 \\
\mathrm{~mm}\end{array}$ & $\begin{array}{l}\text { Long-cone technique } \\
\text { and noncustomized } \\
\text { paralleling device }\end{array}$ & Not reported & $\begin{array}{l}\text { Reference: border between the conical and } \\
\text { the cylindric parts of the implant head } \\
\text { or the abutment-implant connection }\end{array}$ \\
\hline $\begin{array}{l}\text { Corrente } \\
\text { et al. (15) }\end{array}$ & $\begin{array}{l}5 \text { and } \\
7 \mathrm{~mm}\end{array}$ & $\begin{array}{l}\text { Paralleling technique by } \\
\text { means of Rinn film holders }\end{array}$ & Not reported & Not reported \\
\hline $\begin{array}{l}\text { Rossi et } \\
\text { al. (12) }\end{array}$ & $6 \mathrm{~mm}$ & $\begin{array}{l}\text { Standardized radiographs } \\
\text { obtained using individually } \\
\text { fabricated film holders }\end{array}$ & Not reported & $\begin{array}{l}\text { Measurements on radiographs were } \\
\text { performed to assess the bone loss around } \\
\text { the implants at mesial and distal aspects }\end{array}$ \\
\hline $\begin{array}{l}\text { Maló et } \\
\text { al. (11) }\end{array}$ & $7 \mathrm{~mm}$ & $\begin{array}{l}\text { Paralleling technique } \\
\text { with a film holder }\end{array}$ & Not reported & $\begin{array}{l}\text { Reference points: implant platform } \\
\text { and marginal bone remodeling }\end{array}$ \\
\hline $\begin{array}{l}\text { Perelli et } \\
\text { al. (16) }\end{array}$ & $\begin{array}{l}5 \text { and } \\
7 \mathrm{~mm}\end{array}$ & $\begin{array}{l}\text { Digital Rx using paralleling } \\
\text { technique by means of } \\
\text { Rinn film holders }\end{array}$ & Not reported & Not reported \\
\hline $\begin{array}{l}\text { De Santis } \\
\text { et al. (17) }\end{array}$ & $\begin{array}{l}7 \text { and } \\
8.5 \mathrm{~mm}\end{array}$ & Not reported & Not reported & $\begin{array}{l}\text { Bone levels were assessed mesially and } \\
\text { distally by identifying the lowest point } \\
\text { of bone in contact with implant }\end{array}$ \\
\hline $\begin{array}{l}\text { Cannizzaro } \\
\text { et al. (8) }\end{array}$ & 6.5 & Paralleling technique & $\begin{array}{l}\text { X-rays images were calibrated } \\
\text { by the known distance of } \\
\text { two consecutive treads. }\end{array}$ & $\begin{array}{l}\text { Coronal margin of implant collar } \\
\text { and most coronal point of bone- } \\
\text { implant contact (mesial and distal) }\end{array}$ \\
\hline $\begin{array}{l}\text { Mertens et } \\
\text { al. (18) }\end{array}$ & $\begin{array}{l}8 \text { and } \\
9 \mathrm{~mm}\end{array}$ & $\begin{array}{l}\text { Long-cone technique } \\
\text { and a film holder }\end{array}$ & $\begin{array}{l}\text { Linear dimensions calibrated } \\
\text { considering the distance } \\
\text { between the implant threads }\end{array}$ & $\begin{array}{l}\text { Distance from the implant shoulder } \\
\text { and the first visible bone-to-implant } \\
\text { contact (mesial and distal) }\end{array}$ \\
\hline $\begin{array}{l}\text { Pieri et } \\
\text { al. (19) }\end{array}$ & $6 \mathrm{~mm}$ & $\begin{array}{l}\text { Long-cone paralleling } \\
\text { technique and an } \\
\text { individual film holder }\end{array}$ & $\begin{array}{l}\text { Calibration based on the known } \\
\text { diameter of the implant head. } \\
\text { Method error assessed on duplicate } \\
\text { measure of one implant randomly } \\
\text { selected in each patient }\end{array}$ & $\begin{array}{l}\text { Distance from the } \\
\text { implant-abutment junction and the } \\
\text { most coronal level of the bone in } \\
\text { contact with the implant surface }\end{array}$ \\
\hline $\begin{array}{l}\text { Telleman } \\
\text { et al. (9) }\end{array}$ & $8.5 \mathrm{~mm}$ & $\begin{array}{l}\text { Paralleling technique and } \\
\text { an individualized holder }\end{array}$ & $\begin{array}{l}\text { Calibration based on the known } \\
\text { distance of the threads. Reliability } \\
\text { of the X-ray measures assessed } \\
\text { in } 30 \text { X-rays of } 20 \text { patients by } \\
\text { two examiners }(\mathrm{ICC}=0.87)\end{array}$ & Not specified \\
\hline $\begin{array}{l}\text { Telleman } \\
\text { et al. (10) }\end{array}$ & $8.5 \mathrm{~mm}$ & $\begin{array}{l}\text { Paralleling technique and } \\
\text { an individualized holder }\end{array}$ & $\begin{array}{l}\text { Calibration based on the known } \\
\text { distance of the threads. Reliability } \\
\text { assessed in } 30 \mathrm{X} \text {-rays of } 20 \text { patients } \\
\text { by two examiners }(\mathrm{ICC}=0.87)\end{array}$ & Not reported \\
\hline $\begin{array}{l}\text { Kim et } \\
\text { al. (20) }\end{array}$ & $7 \mathrm{~mm}$ & Parallel cone technique & Not reported & $\begin{array}{l}\text { Distance from the implant platform to } \\
\text { the first bone-to implant contact. }\end{array}$ \\
\hline
\end{tabular}


majority installed in the posterior region (61.5\%) of both dental arches (46\%). Nine commercially available implant systems were described including Endopore implants (Innova, Toronto, Canada), machined implants (Nobel Biocare, Göteborg, Sweden), SLActive implants (Straumann, Waldenburg, Switzerland), Nobelspeedy Shorty implants (Nobel Biocare, Zurich, Switzerland), Nanotite XP Certain and Nanotite Certain Prevail implants (Biomet 3i dental implants, Palm Beach, USA), TiOblast and OsseoSpeed implants (Astra Tech AB, Mölndal, Sweden), and Superline implants (Dentium, Suwon, Korea).

In most of the selected studies, the prosthetic treatment considered was the single crowns (77\%), followed by splinted fixed prostheses (46.2\%) and removable implant-

\begin{tabular}{|c|c|c|c|}
\hline Mean marginal bone loss & Crown-implant (C/l) ratio & Crown-implant ratio results & $\begin{array}{l}\text { Cumulative } \\
\text { implant survival }\end{array}$ \\
\hline $\begin{array}{l}\text { Mean bone loss of } 0.03 \mathrm{~mm} \\
\text { (baseline and } 6 \text { months); bone gain } \\
\text { of } 0.12 \mathrm{~mm},(1 \text { to } 2 \text { years) }\end{array}$ & Not reported & Not reported & $100 \%$ \\
\hline Mean bone loss was $0.74 \pm 0.65 \mathrm{~mm}$ & $\begin{array}{l}\text { Anatomical } \mathrm{Cl} \text { ratio: relationship } \\
\text { between crown length (top of the } \\
\text { restoration to the abutment-implant } \\
\text { interface) and implant length }\end{array}$ & $\begin{array}{l}\text { Relatively few } \mathrm{C} / 1 \text { ratios } \\
\text { were }<1 \text { or }>2(16.2 \%)\end{array}$ & $\begin{array}{l}\quad 95.5 \% \\
\text { (reported in } \\
\text { Tawil et al. (32)) }\end{array}$ \\
\hline $\begin{array}{l}\text { Mean bone loss of } 1.0 \mathrm{~mm} \text { (5-mm } \\
\text { implants) and } 2 \mathrm{~mm} \text { (7-mm implants) }\end{array}$ & Not reported & Not reported & $97.9 \%$ \\
\hline $\begin{array}{l}\text { Mean bone loss of } 0.75 \pm 0.71 \mathrm{~mm} \text { (insertion } \\
\text { to } 2 \text {-year follow-up) and } 0.43 \pm 0.49 \\
\mathrm{~mm} \text { (loading to } 2 \text {-year follow-up) }\end{array}$ & $\begin{array}{l}\text { Clinical } \mathrm{Cl} \text { ratio: relationship between } \\
\text { the anatomic crown (top of the } \\
\text { restoration to the most coronal bone- } \\
\text { to-implant contact) and total length } \\
\text { of the implant embedded in bone }\end{array}$ & $\begin{array}{l}\mathrm{C} / 1 \text { ratio was } 1 \pm 0.2 \\
\text { (range } 0.7-1.4 \text { ) }\end{array}$ & $95 \%$ \\
\hline $\begin{array}{l}\text { Mean bone loss } 1.27 \pm 0.67 \\
\text { mm ( } 1 \text { year of follow-up) }\end{array}$ & Not reported & Not reported & $95.4 \%$ \\
\hline $\begin{array}{l}\text { Mean bone loss of } 1.0 \mathrm{~mm} \text { (5-mm } \\
\text { implants) and } 2 \mathrm{~mm} \text { (7-mm implants) } \\
\text { (never exceeding smooth collar) }\end{array}$ & Not reported & Not reported & $84 \%$ \\
\hline $\begin{array}{c}\text { Mean bone loss of } 0.6 \pm 0.2 \\
\mathrm{~mm} \text { (range } 0.0 \text { to } 1.9 \mathrm{~mm} \text { ) }\end{array}$ & Not reported & Not reported & $96.3 \%$ \\
\hline $\begin{array}{l}\text { Mean bone loss of } 0.37 \mathrm{~mm} \text { (immediate } \\
\text { loading) and } 0.31 \mathrm{~mm} \text { (early loading) }\end{array}$ & Not reported & Not reported & $93.3 \%$ \\
\hline $\begin{array}{l}\text { Mean bone loss of } 0.3 \pm 0.5 \\
\mathrm{~mm} \text { (range } 0 \text { to } 1.4 \mathrm{~mm} \text { ) }\end{array}$ & Not reported & Not reported & $100 \%$ \\
\hline $\begin{array}{l}\text { Mean bone loss of } 0.27 \pm 0.10 \mathrm{~mm} \\
\text { (prosthetic loading); } 0.40 \pm 0.23 \mathrm{~mm} \\
\text { (6 months), } 0.51 \pm 0.38 \mathrm{~mm}(1 \text { year }) \\
\text { and } 0.60 \pm 0.13 \mathrm{~mm} \text { ( } 2 \text { years })\end{array}$ & $\begin{array}{l}\text { Clinical } \mathrm{Cl} \text { ratio: relationship between } \\
\text { crown length (top of the restoration to the } \\
\text { most coronal bone-to-implant contact) } \\
\text { and implant length embedded in bone }\end{array}$ & $\begin{array}{l}\text { Mean clinical Cl ratio } \\
\quad \text { was } 1.94 \pm 0.46\end{array}$ & $96.8 \%$ \\
\hline $\begin{array}{l}\text { Mean bone loss was less around platform- } \\
\text { switched }(0.5 \pm 0.53 \mathrm{~mm}) \text { than in } \\
\text { control implants }(0.74 \pm 0.61 \mathrm{~mm})\end{array}$ & Not reported & Not reported & $\begin{array}{l}\text { Control group } \\
92.1 \% ; \text { Test } \\
\text { group } 95.9 \%\end{array}$ \\
\hline $\begin{array}{l}\text { Mean inter-proximal bone loss were less } \\
\text { around platform-switched }(0.51 \pm 0.51 \mathrm{~mm}) \\
\text { than in control implants }(0.73 \pm 0.48 \mathrm{~mm})\end{array}$ & Not reported & Not reported & $\begin{array}{l}\text { Control group } \\
93.1 \% ; \text { Test } \\
\text { group } 94.5 \%\end{array}$ \\
\hline $\begin{array}{l}\text { Mean bone loss of } 0.04 \mathrm{~mm} \text { (two- } \\
\text { stage) and } 0.16 \mathrm{~mm} \text { (one-stage) }\end{array}$ & $\begin{array}{l}\text { Anatomic } \mathrm{Cl} \text { ratio: relationship between } \\
\text { the crown and implant length regardless } \\
\text { the bone level, }(\mathrm{Cl} \text { ratio }<1.5 \text { or } \geq 1.5 \text { ) }\end{array}$ & $\begin{array}{l}\mathrm{Cl} \text { ratios } \geq 1.5 \text { displaying } \\
\text { higher pocket depth than } \\
\text { the group with } \mathrm{Cl} \text { ratio }<1.5\end{array}$ & $97.8 \%$ \\
\hline
\end{tabular}


retained prostheses (7.7\%) (Table 1). The materials applied in these prostheses were described in 9 studies and included metal-ceramic (89\%) and gold-palladium-ceramic crowns (11\%), besides provisional acrylic crowns (22\%).

\section{Cumulate Implant Survival Rate}

All the 13 studies informed the cumulative implant survival rate, which allows the meta-analysis (Fig 2). From the total of 1260 implants placed in 687 patients, 49 were reported to be lost. Thirty implants were lost before loading (61.2\% of all placed implants) and nineteen implants were lost in the follow-up period, after loading (38.8 \% of all placed implants).

The cumulative implant survival rate derived from the data of each study ranged from $84 \%$ at 5 years (16) to $100 \%$ at $2(13)$ to 10 years (18), being the mean overall failure rate of $3.9 \%$. The effect size range from 0.052 $(Z=19.8 ; p<0.001)$ to $0.042(Z=12.83 ; p<0.001)$ at fixed and random model analysis, respectively. The highest relative fixed weight found was 20.45 from Maló et al. 2011 (11) and the heterogeneity was significant $(12=54.3 \% ; p=0.01)$.

Different reasons were pointed out for the early failure including smoking habits $(8,12,19)$, lack of primary stability (12), possible overheating of the parent bone (15), high insertion torque ( $\geq 60 \mathrm{Ncm}$ ) applied during the implant's placement in dense bone of mandible site (19), and problems in the osseointegration process (11). Concerning the late failure, the main causes highlighted were fracture of an implant placed in a patient with bruxer habits (14), periimplantitis $(16,17)$, poor oral hygiene (17), smoking habits (17), occlusal overloading that leads to excessive marginal bone loss (17), and loss of osseointegration without specific reasons $(14,17,20)$.

\section{Implant Surface}

With respect to implant surface treatment, almost all

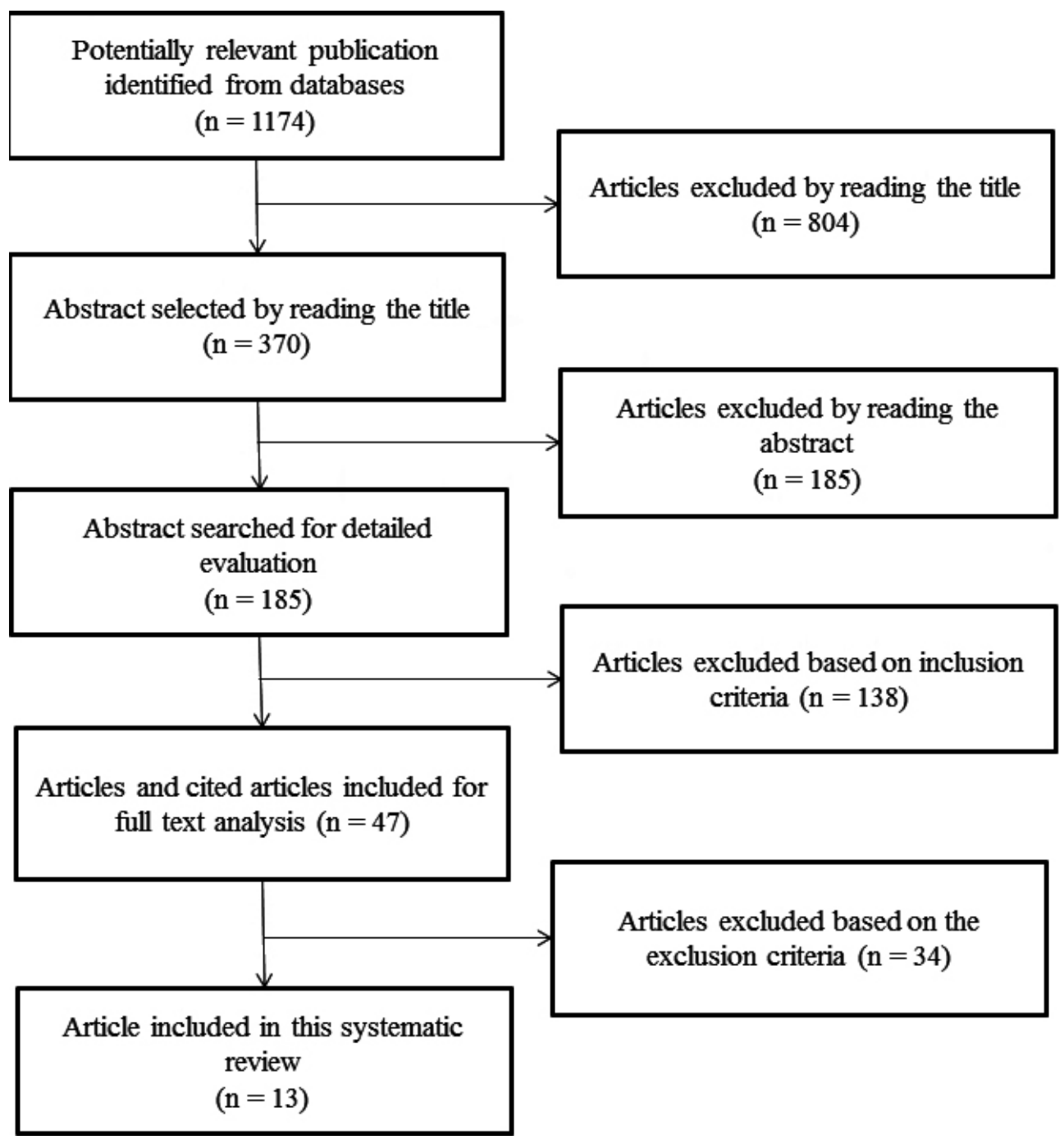

Figure 1. Flow chart of the search strategy. 
articles reported the type of implant surfaces, standing out the porous sintered surface treated with spherical titanium particles $(13,15,16)$, SLActive surfaces (modified (12) or not $(20))$, anodically oxidised surfaces $(11,17)$, dual etched surfaces (covered or not with nanoscale calcium phosphate crystal (8-10), moderately rough titanium-blasted surface (18), and non-treated machined-surface (14).

\section{Crown-to-Implant Ratio}

The crown-to-implant ratio was measured in four of the thirteen studies as a possible deleterious influence for short implants survival (Table 2). In these four articles, the measurements of the crown-to-implant ratio were approached differently. Two studies $(14,20)$ assessed the anatomical crown-to-implant ratio, which considers the fulcrum established at the interface between the implant shoulder and the crown-abutment complex (21). The other two articles $(12,19)$ described the use of the clinical crown-to-implant ratio, where the fulcrum is positioned at the most coronal bone-implant contact. Regardless the considered crown-to-implant ratio, the majority of the implants reported by these four studies presented crown-to-implant ratio between 1 and 2, with extreme situations of crown-to-implant ratio $>2(16.2 \%)$ stated in only one study (14).

\section{Marginal Bone Loss}

Marginal bone loss was calculated in all the selected studies, with the mean values varied from 0 to $2 \mathrm{~mm}$; however differences on the reference points used to measure this outcome and the placement of the implants in different levels of the crestal bone could be remarked. Most of the selected studies $(8,11,17-20)$ considered the distance between the implant platform/shoulder or implant-abutment junction and marginal bone remodeling or the first visible bone-to-implant contact as references to measure the marginal bone loss (Table 2). However, other references such as the position of the alveolar bone at the machined/porous surface junction of the implant root component and the border between the conical and the cylindrical parts of the implant head are also cited as references $(13,14)$. Besides the quantitative value of the marginal bone loss, some studies $(18,19)$ have also considered standard success criteria such as those proposed by Albrektsson and Zarb (22) or Karoussis et al. (23), which defines as successful the implant with vertical bone loss no greater than $1.5 \mathrm{~mm}$ during the first year of loading and $0.2 \mathrm{~mm}$ per year during the following years.

\section{Mechanical Complications}

Six studies recorded biomechanical complications which includes screw loosening $(14,19)$, porcelain fracture $(14,18)$, occlusal overloading (17), food accumulation in interdental spaces (8), crown decementation or fracture $(8,19)$, and implant or component fracture (19). In the remaining studies $(9,10,12,13,15,16,20)$, no further information was given in respect to biomechanical assessment of the short implants.

\section{Biological Complications}

Biological complications in the tissue surrounding short implants were reported in ten of the thirteen studies. The most cited parameters assessed were the Plaque Index (regular $(12,17,20)$ or modified $(9,10,18,19)$ ), modified Sulcus Bleeding Index $(9,10,12,18,19)$, Gingival Index $(9,10,17,20)$, probing pocket depth $(9,10,12,17-20)$, mobility of implants $(8,18)$, presence of dental calculus $(9,10)$, width of keratinized mucosa (19), resonance frequency analysis (19), $\underline{\text { Study name }}$

$-0.50$

\begin{tabular}{|c|c|c|c|c|c|}
\hline \multirow[t]{2}{*}{$\underline{\text { Study name }}$} & \multicolumn{5}{|c|}{$\underline{\text { Statistics for each study }}$} \\
\hline & $\begin{array}{c}\text { Event } \\
\text { rate }\end{array}$ & $\begin{array}{c}\text { Lower } \\
\text { limit }\end{array}$ & $\begin{array}{r}\text { Upper } \\
\text { limit }\end{array}$ & Z-Value & -Value \\
\hline Deporter et al. 2001 & 0.010 & 0.001 & 0.143 & -3.218 & 0.001 \\
\hline Tawil et al. 2006 & 0.008 & 0.002 & 0.030 & -6.857 & 0.000 \\
\hline Corrente et al. 2009 & 0.021 & 0.003 & 0.134 & -3.810 & 0.000 \\
\hline Rossi et al. 2010 & 0.050 & 0.013 & 0.179 & -4.059 & 0.000 \\
\hline Maló et al. 2011 & 0.046 & 0.025 & 0.084 & -9.359 & 0.000 \\
\hline Perelli et al. 2011 & 0.164 & 0.087 & 0.286 & -4.476 & 0.000 \\
\hline De Santis et al. 2011 & 0.037 & 0.014 & 0.095 & -6.374 & 0.000 \\
\hline Cannizzaro et al., 2012 & 0.033 & 0.008 & 0.124 & -4.682 & 0.000 \\
\hline Mertens et al. 2012 & 0.009 & 0.001 & 0.134 & -3.275 & 0.001 \\
\hline Pieri et al. 2012 & 0.033 & 0.008 & 0.122 & -4.707 & 0.000 \\
\hline Telleman et al. 2012 & 0.061 & 0.029 & 0.122 & -7.016 & 0.000 \\
\hline Telleman et al. 2013 & 0.060 & 0.032 & 0.112 & -7.981 & 0.000 \\
\hline Kim et al. 2013 & 0.022 & 0.003 & 0.139 & -3.765 & 0.000 \\
\hline & 0.052 & 0.040 & 0.068 & -19.805 & 0.000 \\
\hline
\end{tabular}

Event rate and $95 \% \mathrm{CI}$

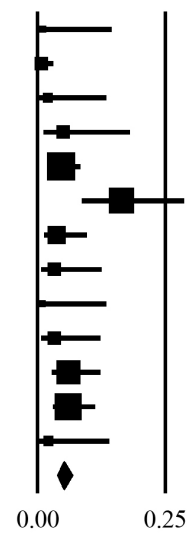

Weight (Fixed)

Relative Relative Std Std Std weight weight Residual Residual Residual

Figure 2. Forest plot of cumulative implant survival rate and subgroup analysis per study design. 
peri-implant pathology $(11,16)$, soft tissue inflammation (11), fistula formation (11), and pain (11). Peri-implantitis $(8,11,16,17)$ was the most prevalent complication observed in the soft tissue followed by excessive probing pocket depths $(\geq 6 \mathrm{~mm})(11,18,19)$, poor hygiene $(17)$, mild pain and swelling (19), transient paresthesia (19), and bleeding on probing (11). Regarding the conducted treatment, only two studies cited such information, reporting the subgengival cleaning, open flap cleaning, bone tissue regeneration and a strict maintenance program $(8,17)$. In cases of implant loss as a consequence of biological failure, most of the studies described the replacement of the referred short implants after a period of healing, without any further complication $(11,19)$. As regards the clinical parameters, it was noticed a good oral hygiene, with stable condition of gingival tissue around implants with tendency to bleeding on probing but predominantly weak, and probing depth $<5 \mathrm{~mm}$ in most of the cases $(9,10,12,18,19)$.

\section{Esthetical Complications}

Only one study (8) assessed the esthetical appearance as a primary outcome measurement, describing the $\vec{\sigma}$ replacement of the single crown due to patient satisfaction. The remaining articles did not assessed or not reported any esthetical complication.

\section{Discussion}

The main purpose of the current systematic review was to investigate the essential parameters required to assess the long-term clinical performance of short and extrashort dental implants. By means of this literature review, a standard evaluation protocol is proposed (Fig. 3), being helpful to regiment further investigations. The included articles embraced a wide range of approaches including the study design, data reporting, terms and definitions, measurements, implants system, and follow-up period of time. Concerning the short implants definition, several differences could be noticed in literature. Therefore, the definition of endosseous dental implant that has a 'designed intrabony length' less or equal to $8 \mathrm{~mm}$, proposed by Renouard et al. (24) was chosen to guide the search of the articles.

From the thirteen articles selected, the cumulative implant survival rate was the most common parameter assessed, ranging from $84 \%$ at 5 years (16) to $100 \%$ at 2 (13) to 10 years (18). Data meta-analysis revealed positive effect size varying from $0.052(Z=19.8 ; p<0.001)$ to 0.042 $(Z=12.83 ; p<0.001)$ at fixed and random analysis, which means that the provision of short implant in atrophic alveolar ridges appears to be a successful treatment option. Similar results were described in a former systematic review (25), even though the survival rates have being assessed in regards to implants placed in bone augmentation sites or guided bone regeneration technique (varying from 79.5\% to $100 \%$ ). In addition, authors suggested that despite the favorable results of standard implants associated with bone grafts, the priority should be given to simpler approaches such as short implants (25). According to Annibali et al. (26), short implants should not be compared to longer implants placed in the native jawbone. The most suitable comparison should be performed between short implants and advanced surgical techniques, necessary to place longer implants in resorbed posterior jaws (26). In this context, due to the lack of randomized clinical trials, it was impossible to demonstrate that such augmentation procedures are actually needed to allow the long-term survival of implants or if the use of short implants is indeed a better choice (25).

The typical method of calculating survival in most studies is another point of concern because several studies apply a simple ratio between the number of implants removed and the total number of implants placed. This method is misleading since it does not take into account the effects of time (27). Moreover, important clinical aspects not considered on the implants evaluation should be assessed because they are closely related to failures, especially in short dental implants. Factors such as patient's habits (smoking, bruxism and clenching); presence of systemic diseases (alcoholism, diabetes and osteoporosis); features related to implant insertion (primary stability, insertion torque, bone density, position of the implant in respect to the bone ridge and loading protocol); characteristics of the implants (brand, surface treatment, length, diameter, shape and implant-abutment connection); particularities of the prosthesis (screwed or cemented, type of abutment, single or multiple, length of the cantilever, occlusion, material, crown length and antagonist occlusion); and biological parameters (periodontal tissue and hygiene condition assessment) should be always assessed in the clinical practice. Thus, the development of standard criteria encompassing all these parameters would be helpful to regiment further investigations and allows comparisons in future studies.

Recent literature has credit the increased survival rate of short implants to the surface structure because of the higher bone-to-implant contact $(4,18)$. Therefore, it is crucial to describe, in a standard survey, the surface characteristics as well as the degree of roughness of the implant system applied. The majority of studies selected in this review, except one (19), described the type of surface, being the moderate rough surfaces selected in most of the cases. The detailed description of the implant system increases the reproducibility of the study and allows the comparison of results. Thus, it is possible to find out what is the most successful surface to be used in short dental implants (12). 


\section{Proposed Protocol}

\begin{tabular}{|c|c|c|c|}
\hline Biological Parameters & Baseline & Follow-up 1 & Follow-up 2 \\
\hline \multicolumn{4}{|l|}{ Plaque Index } \\
\hline \multicolumn{4}{|l|}{ Bleeding index } \\
\hline \multicolumn{4}{|l|}{ Probing depth } \\
\hline \multicolumn{4}{|l|}{ Pain (VAS) } \\
\hline Observation: & & Yes & No \\
\hline \multicolumn{4}{|c|}{ Parafunction (bruxism and or clenching) } \\
\hline \multicolumn{4}{|c|}{ Smoking habits } \\
\hline \multicolumn{4}{|l|}{ Diabetes } \\
\hline \multicolumn{4}{|l|}{ Alcoholism } \\
\hline \multicolumn{4}{|l|}{ Osteoporosis } \\
\hline Radiotherapy in the heac & & & \\
\hline
\end{tabular}

Medical history: patients with a history of myocardial infarction, heart failure, valvular disease, cancer developed, hemophilia, anemia, osteoporosis, diabetes and AIDS

\begin{tabular}{|l|c}
\hline Implant Parameters & Implant region \\
\hline Brand & \\
\hline Lenght & \\
\hline Diameter & \\
\hline Surface treatment & \\
\hline Shape & \\
\hline Abutment connection & \\
\hline
\end{tabular}

\begin{tabular}{|l|c}
\hline Surgical Parameters & Implant region \\
\hline Bone level & \\
\hline Location & \\
\hline Bone density & \\
\hline Insertion torque & \\
\hline Loading protocol & \\
\hline Primary stability & \\
\hline Healing caps (submerged or transmucosal) & \\
\hline Special surgical technique (mini sinus lift, split crest) & \\
\hline Biomaterial (CGF, Collagen, novocore) & \\
\hline
\end{tabular}

\begin{tabular}{|l|l}
\hline Prosthetic Parameters & \multicolumn{1}{c}{ Data } \\
\hline Location & \\
\hline Distance between implants & \\
\hline Type of prosthesis & \\
\hline Type of abutments & \\
\hline Splinted (Yes/no) & \\
\hline Prosthesis material & \\
\hline Cemented or screwed & \\
\hline Platform switching concept: yes/no & \\
\hline Cantilever Length (mm) & \\
\hline Occlusion & \\
\hline
\end{tabular}

\begin{tabular}{|l|l|l|l}
\hline Radiographic Parameters & Baseline & Follow-up 1 & Follow-up 2 \\
\hline Anatomical crown length (mm) & & & \\
\hline Implant length $(\mathrm{mm})$ & & & \\
\hline Crown height space (mm) & & & \\
\hline Resorption $(\mathrm{mm})$ & & & \\
\hline Bone gain $(\mathrm{mm})$ & & & \\
\hline
\end{tabular}

Bone gain $(\mathrm{mm})$

\section{Additional parameters}

Integrity of the prosthesis:

1) Major failures:

fracture of the bridge - yes / no fracture of the implant - yes / no infection - yes / no implant mobility or removal - yes / no before loading after loading

2) Minor failures:

fracture of the retention screw - yes / no fracture of the esthetic veneering - yes / no decementation - yes / no 
Another concern when implants with rough surface are installed is the acute infection in peri-implant area, which may be more common and difficult to treat in the presence of very rough or porous surfaces (28). In spite of that, no attention was given, in these four studies $(8,11,16,17)$ with cases of peri-implantitis and mucosities, to the possible connection between the implant surface and a higher risk of peri-implantititis. Future studies evaluating short implant performance should consider this important aspect.

Based on the clinical performance of conventional crown-to-root, closely susceptible to harmful lateral occlusal forces (29), it was believed that excessive crownto-implant ratio could be detrimental to long-term implant survival, especially when short implants are considered (30). It is because the higher the crown, the longer is the lever arm, and consequently the greater is the stress in marginal bone which could contribute to increase the risk for marginal bone loss $(21,30,31)$. Contrary to this belief, the majority of the selected studies were not able to establish a strictly relation between the crown-to-implant ratio and marginal bone loss (Table 2). The only aspect, underlined in one of the studies (20), was the higher pocket depth (Table 2). Recently, several studies $(21,30,32)$ have shown the absence of a significant association between crownto-implant ratio and marginal bone loss, even in cases of high crown-to-implant ratio of 2.4 (32). Different reasons can be pointed out to explain such fact, including the treatment of the implant surface and the level in which the implant shoulder is placed at the crestal bone. Beyond that, different approaches applied to measure the crownto-implant ratio make it difficult to compare the results.

Another important parameter related to the crownto-implant ratio, not assessed in the selected articles, is the crown height space (32). This measurement represents the vertical distance between the occlusal plane and the alveolar bone level $(32,33)$. Previous studies revealed that the increased crown height space (higher than $15 \mathrm{~mm}$ ) results in higher stress concentrations at the bone-implant interface and significantly marginal bone loss $(32,33)$. Thus, the crown height space is a more effective parameter to study the relationship between the crown-to-implant ratio and marginal bone loss and should be included in the assessment of long-term evaluation of short implant performance (32).

The second parameter assessed in all the selected articles as an important outcome to measure implant success was the mean marginal bone loss. In such parameter, a great range of values were noticed with mean marginal bone loss varying from 0 to $2 \mathrm{~mm}$ after 1 year follow-up. The possible reason for such differences might be the limits used as a reference to measure the marginal bone loss or the placement of the implants in different levels of the crestal bone. For instance, the highest marginal bone loss $(2 \mathrm{~mm})$ observed in two studies $(15,16)$, might be a consequence of the implant system applied, because the system applied presents a rough surface and a smooth collar, being usually placed with the smooth collar submerged in the crestal bone. This characteristic might change the reference when the marginal bone loss is assessed, explaining the higher values encountered. Different assessment of the actual marginal bone loss by different studies should be avoided, because it jeopardizes the outcome interpretation.

The majority of biomechanical complications, reported in the selected studies, were minor issues including screw loosening $(14,19)$, food accumulation in interdental spaces (8), and crown decementation or fracture $(8,14,18,19)$. All these problems are easily solved by the replacement of the crown, when necessary (8). The only major issue reported was the occlusal overloading, that resulted in excessive bone resorption (17) and, consequently, the loss of osseointegration or implant fracture (19). It is important to notice that most of the failures occurred in posterior location, area with low density bone and high occlusal forces, which could predispose the implants to failure. Accordingly, it is crucial the closely monitoring of the patients by a regular maintenance program, not focusing only in the cleaning of the prosthesis, but attempting to the proper occlusal adjustment to avoid future complications.

Regarding the biological complications, the most prevalent issue reported was the peri-implantitis $(8,11,16,17)$. However, only $13(1 \%)$ of the 1260 implants suffered from inflammation in the peri-implant tissue. The mean reason for this low prevalence of biological complication might be prospective design of the studies besides the maintenance program applied by most of the studies, comprising a professional cleaning and hygiene instruction, with recall visits every 4 to 6 months (1618). It emphasizes the importance of a restrict follow-up monitoring of the patient, assessing different parameters to prevent further and more serious complications, consequently increasing the long-term success of short implants.

In respect to the esthetical issues, only one study (8) reported an issue of unsatisfied patient. It was expected because most of the short implants are installed in posterior regions, where the esthetical requirements are usually low. Although few studies $(8,10,19)$ had reported data among patient satisfaction and preferences, it is important to evaluate these subjective parameters because they are closely related to the survival rate, especially regarding the long-term success of the prosthesis.

The present review is a primary vision of this vast field of research. Thereby, it is impossible to guarantee that 
all parameters used in the follow-up evaluation of short implants were included because it requires a much more extensive description of literature, not usual in a systematic review. Moreover, a specific evaluation regarding the risk of bias of each selected study was not applied in the present review mainly because only few randomized clinical trials were included and the principal focus of the study was the parameters used for the implant assessment, not the result itself. In spite of that, it is important summarize the most common aspects pointed out in recent literature to evaluate implant performance, since it could fundament the development of standardized protocols in the near future. By means of this literature review, a standard evaluation scheme is being proposed and detailed (Complementary file) to regiment further investigations and be helpful to comparison in future studies.

The findings from this systematic review highlight different parameters, besides the implant survival rate and marginal bone loss, which are important to be observed in the long-term monitoring of the patients with short implant. By means of this literature review, a standard scheme is proposed to be used in the follow-up appointments, encompassing:

1. Patient's habits (smoking, bruxism and clenching) and systemic condition (alcoholism, diabetes, osteoporosis and medicine prescription);

2. Features related to implant insertion (primary stability, insertion torque, bone density, position of the implant in respect to the bone ridge and loading protocol);

3. Characteristics of the implants (brand, surface treatment, length, diameter, shape and implant-abutment connection);

4. Particularities of the prosthesis (screwed or cemented, type of abutment, single or multiple, length of the cantilever, occlusion, material, crown length, antagonist occlusion, $\mathrm{C} / \mathrm{I}$ ratio and crown height space);

5. Biological parameters (periodontal tissue and hygiene condition assessment).

Combined with a well-established maintenance program, this standard protocol configures as an important instrument for the decision-making process, regimenting further investigations and comparisons on future studies.

\section{Resumo}

A falta de critérios padronizados para a avaliação dos resultados faz com que seja difícil tirar conclusões sobre o desempenho clínico dos implantes curtos e, nestas circunstâncias, determinar as razões para o fracasso do implante. Este estudo avaliou, através de uma revisão sistemática da literatura, os parâmetros essenciais necessários para avaliar o desempenho clínico em longo prazo de implantes curtos e extra-curtos. Bases de dados eletrônicas (PubMed-MEDLINE, Base de dados da Biblioteca Cochrane, Embase e Lilacs) foram avaliadas por dois revisores independentes, sem limitação da linguagem, de modo a identificar artigos elegiveis. As referências dos artigos selecionados foram também analisadas. A revisão incluiu estudos clínicos, publicados entre janeiro de 2000 e março de 2014, envolvendo implantes dentais curtos, instalados em seres humanos, nos quais foram descritos os parâmetros utilizados para mensuração dos resultados e fornecidos dados sobre as taxas de sobrevivência. Treze estudos metodologicamente aceitáveis foram selecionados, sendo identificados 24 parâmetros. Os parâmetros avaliados com maior frequencia foram a perda óssea marginal e a taxa cumulativa de sobrevivência do implante, seguida pela taxa de falha dos implantes e complicações biológicas, tais como sangramento à sondagem e profundidade de sondagem. Apenas a taxa cumulativa de sobrevivência dos implantes permitiu a meta-análise revelando efeito positivo (variação de 0.052 (efeito fixo) até 0.042 (efeito aleatório)), demonstrando que os implantes curtos parecem ser uma opção de tratamento bem sucedida. Complicações mecânicas e a mensuração da proporção coroa-implante foram também referidas, entretanto, considerando-se as evidências disponíveis, não se pode chegar a fortes conclusões, pois diferentes métodos foram utilizados para avaliar cada parâmetro. Por meio desta revisão da literatura, um esquema padronizado de avaliação é proposto, sendo útil para arregimentar novas investigações e permitir a comparação de estudos futuros.

\section{References}

1. Romeo E, Bivio A, Mosca D, Scanferla M, Ghisolfi M, Storelli S. The use of short dental implants in clinical practice: literature review. Minerva Stomatol 2010;59:23-31.

2. Lee $J H$, Frias V, Lee KW, Wright RF. Effect of implant size and shape on implant success rates: a literature review. J Prosthet Dent 2005;94:377381.

3. Weng D, Jacobson Z, Tarnow D, Hurzeler MB, Faehn O, Sanavi F, et al.. A prospective multicenter clinical trial of $3 \mathrm{i}$ machined-surface implants: results after 6 years of follow-up. Int J Oral Maxillofac Implants 2003;18:417-423.

4. Telleman G, Raghoebar GM, Vissink A, den Hartog L, Huddleston Slater $J J$, Meijer HJ. A systematic review of the prognosis of short $(<10 \mathrm{~mm})$ dental implants placed in the partially edentulous patient. J Clinic Periodontol 2011;38:667-676.

5. Misch CE, Steignga J, Barboza E, Misch-Dietsh F, Cianciola U, Kazor C. Short dental implants in posterior partial edentulism: a multicenter retrospective 6-year case series study. J Periodontol 2006;77:13401347.

6. Atieh MA, Zadeh $H$, Stanford CM, Cooper LF. Survival of short dental implants for treatment of posterior partial edentulism: a systematic review. Int J Oral Maxillofac Implants 2012;27:1323-1331.

7. Sterne JA, Egger M, Smith GD. Systematic reviews in health care: Investigating and dealing with publication and other biases in metaanalysis. BMJ 2001;323:101-105.

8. Cannizzaro G, Felice P, Leone M, Ferri V, Viola P, Esposito M. Immediate versus early loading of $6.5 \mathrm{~mm}$-long flapless-placed single implants: a 4-year after loading report of a split-mouth randomised controlled trial. Eur J Oral Implantol 2012;5:111-121.

9. Telleman G, Meijer HJ, Vissink A, Raghoebar GM. Short implants with a nanometer-sized $\mathrm{CaP}$ surface provided with either a platform-switched or platform-matched abutment connection in the posterior region: a randomized clinical trial. Clin Oral Implants Res 2013;24:1316-1324.

10. Telleman G, Raghoebar GM, Vissink A, Meijer HJ. Impact of platform switching on inter-proximal bone levels around short implants in the posterior region; 1 -year results from a randomized clinical trial. J Clinic Periodontol 2012;39:688-697.

11. Malo P, Nobre M, Lopes A. Short implants in posterior jaws. A prospective 1-year study. Eur J Oral Implantol 2011;4:47-53.

12. Rossi F, Ricci E, Marchetti C, Lang NP, Botticelli D. Early loading of single crowns supported by 6 -mm-long implants with a moderately rough surface: a prospective 2-year follow-up cohort study. Clin Oral Implants Res 2010;21:937-943.

13. Deporter D, Pilliar RM, Todescan R, Watson P, Pharoah M. Managing the posterior mandible of partially edentulous patients with short, porous-surfaced dental implants: early data from a clinical trial. Int J Oral Maxillofac Implants 2001;16:653-658.

14. Tawil G, Aboujaoude N, Younan R. Influence of prosthetic parameters 
on the survival and complication rates of short implants. Int J Oral Maxillofac Implants 2006;21:275-282.

15. Corrente G, Abundo R, des Ambrois AB, Savio L, Perelli M. Short porous implants in the posterior maxilla: a 3-year report of a prospective study. Int J Periodontics Restorative Dent 2009;29:23-29.

16. Perelli M, Abundo R, Corrente G, Saccone C. Short ( 5 and $7 \mathrm{~mm}$ long) porous implant in the posterior atrophic mandible: a 5-year report of a prospective study. Eur J Oral Implantol 2011;4:363-368.

17. De Santis D, Cucchi A, Longhi C, Vincenzo B. Short threaded implants with an oxidized surface to restore posterior teeth: 1- to 3-year results of a prospective study. Int J Oral Maxillofac Implants 2011;26:393-403.

18. Mertens C, Meyer-Baumer A, Kappel H, Hoffmann J, Steveling HG. Use of 8-mm and 9-mm implants in atrophic alveolar ridges: 10-year results. Int J Oral Maxillofac Implants 2012;27:1501-1508.

19. Pieri F, Aldini NN, Fini M, Marchetti C, Corinaldesi G. Preliminary 2-year report on treatment outcomes for 6-mm-long implants in posterior atrophic mandibles. Int J Prosthodont 2012;25:279-289.

20. Kim YK, Yun PY, Yi YJ, Bae JH, Kim SB, Ahn GJ. One-year prospective study of $7 \mathrm{~mm}$ long implants in mandible: installation technique and crown/implant ratio of 1.5 or less. J Oral Implantol 2013.

21. Blanes RJ. To what extent does the crown-implant ratio affect the survival and complications of implant-supported reconstructions? A systematic review. Clin Oral Implants Res 2009;20:67-72.

22. Albrektsson T, Zarb GA. Determinants of correct clinical reporting. Int J Prosthodont 1998;11:517-521.

23. Karoussis IK, Salvi GE, Heitz-Mayfield $\amalg$, Bragger $\mathrm{U}$, Hammerle $\mathrm{CH}$, Lang NP. Long-term implant prognosis in patients with and without a history of chronic periodontitis: a 10-year prospective cohort study of the ITI Dental Implant System. Clin Oral Implants Res 2003;14:329-339.

24. Renouard F, Nisand D. Impact of implant length and diameter on survival rates. Clin Oral Implants Res 2006;17:35-51.

25. Chiapasco M, Zaniboni M. Clinical outcomes of GBR procedures to correct peri-implant dehiscences and fenestrations: a systematic review. Clin Oral Implants Res 2009;20:113-123.

26. Annibali S1, Cristalli MP, Dell'Aquila D, Bignozzi I, La Monaca G, Pilloni A. Short dental implants: a systematic review. J Dent Res 2012;91:2532.

27. Chrcanovic BR, Albrektsson T, Wennerberg A. Reasons for failures of oral implants. J Oral Rehabil 2014;41:443-476.

28. Esposito $M$, Ardebili $Y$, Worthington HV. Interventions for replacing missing teeth: different types of dental implants. Cochrane Database Syst Rev 2014;7:CD003815.

29. Grossmann Y, Sadan A. The prosthodontic concept of crown-to-root ratio: a review of the literature. J Prosthet Dent 2005;93:559-562.

30. Birdi H, Schulte J, Kovacs A, Weed M, Chuang SK. Crown-to-implant ratios of short-length implants. J Oral Implantol 2010;36:425-433.

31. Rangert BR, Sullivan RM, Jemt TM. Load factor control for implants in the posterior partially edentulous segment. Int J Oral Maxillofac Implants 1997; 12:360-370.

32. Anitua $\mathrm{E}$, Alkhraist $M H$, Pinas $\mathrm{L}$, Begona $\mathrm{L}$, Orive $\mathrm{G}$. Implant survival and crestal bone loss around extra-short implants supporting a fixed denture: the effect of crown height space, crown-to-implant ratio, and offset placement of the prosthesis. Int J Oral Maxillofac Implants 2014;29:682-689.

33. Nissan J, Ghelfan 0, Gross 0, Priel I, Gross M, Chaushu G. The effect of crown/implant ratio and crown height space on stress distribution in unsplinted implant supporting restorations. J Oral Maxillofac Surg 2011;69:1934-1939.

34. Tawil G, Younan R. Clinical evaluation of short, machined-surface implants followed for 12 to 92 months. Int J Oral Maxillofac Implants 2003;18:894-901.
Received October 23, 2014

Accepted April 7, 2015 